\title{
A postsynthetically 2'-"clickable" uridine with arabino configuration and its application for fluorescent labeling and imaging of DNA
}

\author{
Heidi-Kristin Walter ${ }^{1}$, Bettina Olshausen ${ }^{2}$, Ute Schepers ${ }^{2}$ \\ and Hans-Achim Wagenknecht ${ }^{* 1}$
}

Open Access

\author{
Full Research Paper \\ Address: \\ ${ }^{1}$ Institute of Organic Chemistry, Karlsruhe Institute of Technology \\ (KIT), Fritz-Haber-Weg 6, 76131 Karlsruhe, Germany and ${ }^{2}$ Institute of \\ Toxicology and Genetics, Karlsruhe Institute of Technology (KIT), \\ H.-v.-Helmholtz-Platz 1, 76344 Eggenstein-Leopoldshafen, Germany \\ Email: \\ Hans-Achim Wagenknecht ${ }^{*}$ - Wagenknecht@kit.edu \\ * Corresponding author \\ Keywords: \\ dyes; fluorescence; nucleic acid; oligonucleotide
}

Beilstein J. Org. Chem. 2017, 13, 127-137.

doi:10.3762/bjoc.13.16

Received: 17 October 2016

Accepted: 03 January 2017

Published: 20 January 2017

This article is part of the Thematic Series "Chemical biology".

Guest Editor: H. B. Bode

(c) 2017 Walter et al.; licensee Beilstein-Institut.

License and terms: see end of document.

\begin{abstract}
The arabino-configured analog of uridine with a propargyl group at the 2'-position was synthesized and incorporated into DNA by solid-phase chemistry. The fluorescence quantum yields of DNA strands that were postsynthetically modified by blue and green emitting cyanine-styryl dyes were improved due to the arabino-configured anchor. These oligonucleotides were used as energy transfer donors in hybrids with oligonucleotides modified with acceptor dyes that emit in the yellow-red range. These combinations give energy transfer pairs with blue-yellow, blue-red and green-red emission color changes. All combinations of arabino- and riboconfigured donor strands with arabino- and ribo-configured acceptor strands were evaluated. This array of doubly modified hybrids was screened by their emission color contrast and fluorescence quantum yield. Especially mixed combinations, that means donor dyes with arabino-configured anchor with acceptor dyes with ribo-configured anchor, and vice versa, showed significantly improved fluorescence properties. Those were successfully applied for fluorescent imaging of DNA after transport into living cells.
\end{abstract}

\section{Introduction}

The "click"-type reactions [1], in particular the 1,3-dipolar cycloaddition between alkynes and azides (CuAAC) is a broadly applied strategy for postsynthetic oligonucleotide modification since both reactive groups are not present in nucleic acids [2-5]. Although Huisgen described the uncatalyzed reaction yielding 1,2,3-triazoles already in the 1960s [6], the bioorthogonality with respect to proteins and nucleic acids emerged after Sharpless [7] and Meldal [8] had reported that catalysis by $\mathrm{Cu}(\mathrm{I})$ enhances not only reaction rates but improves also regioselectivity. The formation of oligonucleotide oxidation side products by $\mathrm{Cu}(\mathrm{I})$ is avoided by the use of chelating $\mathrm{Cu}(\mathrm{I})$ ligands, in particular tris[(1-benzyl-1H-1,2,3-triazol-4- 
yl)methyl]amine (TBTA) and better water-soluble derivatives $[9,10]$. The CuAAC cannot only be applied for conventional postsynthetic oligonucleotide modification in solution but also on solid phase [11] and for the introduction of multiple postsynthetic modifications [12]. The azide groups for CuAAC are typically placed onto the fluorescent dyes since azides are not compatible with phosphoramidite chemistry. The alkyne groups as reactive precursors are attached to the oligonucleotide [13] especially at the 5-position of pyrimidines [13], the 7-position of 7-deazapurines [14], and the 2'-position of ribofuranosides $[11,15]$. These positions were chosen since they are typically accepted by DNA polymerases in primer extension experiments and PCR $[4,16]$.

To develop fluorescently labelled oligonucleotides that undergo energy transfer reactions [17] we recently applied 2'-propargylmodified uridine $\mathbf{1}$ as DNA building block (Scheme 1) $[15,18,19]$. A simple look on the three-dimensional structure of double-helical DNA elucidates that the positioning of the fluorophores in the major groove may be improved by inversion of the configuration at the 2'-position of the anchor nucleoside sugar. In fact, arabino nucleic acids are an important class of antisense oligonucleotides [20] since their first report [21] The orientation of the 2'-OH group in the arabino configuration towards the major groove yields hybrids with RNA that show a slightly lower thermal stability compared to DNA/RNA hybrids. In order to evaluate this structural influence for our fluorescently labelled oligonucleotides, we developed and synthesized the 2'-propargyl-modified arabino-configured uridine analog 2 , incorporated it into DNA by automated phosphoramidite chemistry, "clicked" it to a variety of our recently established, photostable cyanine-styryl dyes and probed the fluorescence and energy transfer properties by determination of quantum yields and emission color contrasts.
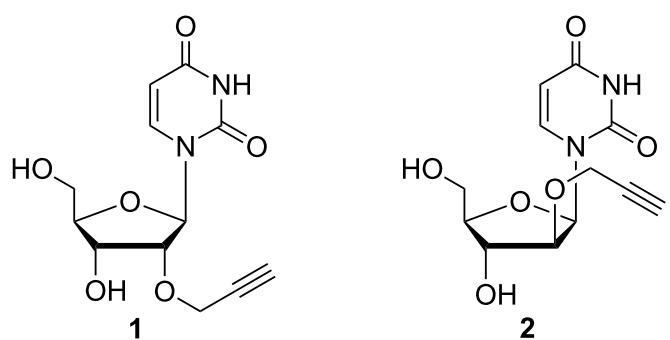

Scheme 1: 2'-Propargylated nucleosides as "clickable" DNA/RNA building blocks with ribo (1) and arabino (2) configuration.

\section{Results and Discussion}

The synthesis of the phosphoramidite 7 (Scheme 2) was straightforward and includes mainly protecting group chemistry since it starts with the commercially available arabino- configured uridine analog 3. The 3'- and 5'-hydroxy functions of nucleoside 3 were selectively protected by the Markiewicz silyl ether [22]. The central step of the whole synthetic procedure was the alkylation of the 2'-OH function of nucleoside 4 by propargylic bromide which worked in $65 \%$ yield in the presence of $\mathrm{NaH}$ as base. After removal of the silyl protecting group from nucleoside $\mathbf{5}$, the 5 '-position of nucleoside $\mathbf{2}$ was again protected by 4,4'-dimethoxytrityl chloride (DMTr-Cl) and, finally, the 3'-position of nucleoside 6 was phosphitylated. Remarkably, the overall yield of phosphoramidite 7 with the optimized conditions over the described five steps is $54 \%$. Automated DNA synthesis with 7 as building block required a slightly extended coupling time of $10 \mathrm{~min}$. The phosphoramidite for the "clickable" nucleoside $\mathbf{1}$ is commercially available. After preparation, the detritylated oligonucleotides DNA1a ("a" = arabino) and DNA1r ("r" = ribo) were cleaved from the resin and deprotected with conc. $\mathrm{NH}_{4} \mathrm{OH}$ at $45{ }^{\circ} \mathrm{C}$ for $16 \mathrm{~h}$. The lyophilized oligonucleotides were reacted with the azide-modified dyes D1-D4 in the presence of $\mathrm{Cu}(\mathrm{I})$ and TBTA, as mentioned above. The reaction was performed in $\mathrm{H}_{2} \mathrm{O} / \mathrm{DMSO} / \mathrm{t}$-BuOH 3:3:1 and was completed after $1.5 \mathrm{~h}$ at $60{ }^{\circ} \mathrm{C}$. The modified oligonucleotides were purified by ethanol precipitation in the presence of EDTA to remove copper ions and subsequently by semi-preparative HPLC. Finally, the modified oligonucleotides were identified by MALDI-TOF mass spectrometry (see Supporting Information File 1) and annealed with the corresponding unmodified counterstrand.

The four fluorophores D1 [23], a blue emitter excitable at 389 nm, D2 [24], D3 [19], and D4 [24], all green emitters excitable at $450-460 \mathrm{~nm}$, that were "clicked" to the oligonucleotides DNA1a and DNA1r belong to our recently established class of cyanine-styryl dyes that show a unique combination of optical properties [25], including suitable brightness and fluorescence quantum yields, large Stokes' shifts compared to conventionally applied Cy 3 and Cy5, and most importantly, excellent photostabilities. D1-D4 were representatively chosen since they will serve as energy donors in the energy transferbased DNA systems (vide infra). The corresponding dye azides were synthesized as previously described [19,23,24]. The modified double strands (ds) DNA2aD1 to DNA2aD4 were compared with their structural counterpart among the duplexes DNA2rD1 to DNA2rD4 with respect to their optical properties (UV-vis absorption and fluorescence, see Supporting Information File 1), fluorescence quantum yields $\Phi_{\mathrm{F}}$ and melting temperatures $T_{\mathrm{m}}$ (Table 1). The reference duplexes of DNA1a and DNA1r annealed with the unmodified complementary strand showed $T_{\mathrm{m}}$ values of $61.0{ }^{\circ} \mathrm{C}$ and $62.0^{\circ} \mathrm{C}$, respectively. This small difference tracks well with the general observation that arabino-configured nucleic acids in general show lower stabilities than the ribo-configured ones. With the attached dyes, the 
<smiles>O=c1ccn(O)c(=O)[nH]1</smiles>

3

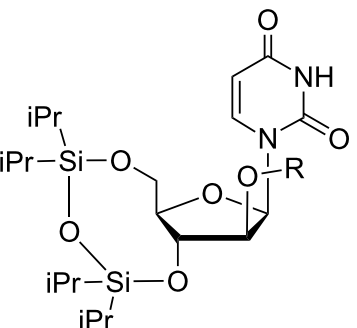

$\mathrm{iPr}$<smiles>[14CH2][14CH2]</smiles>

5: $\mathrm{R}=\mathrm{CH}_{2}=$

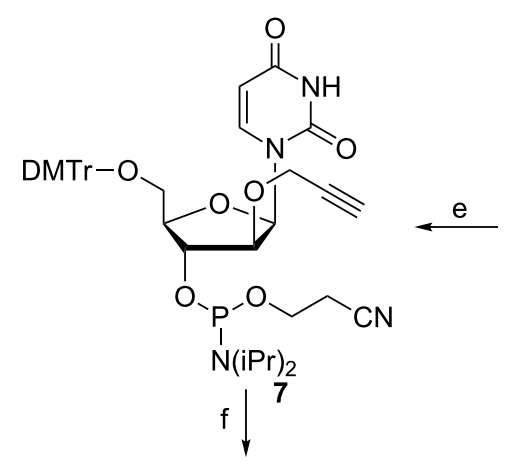<smiles></smiles><smiles>[R]O[K]</smiles>

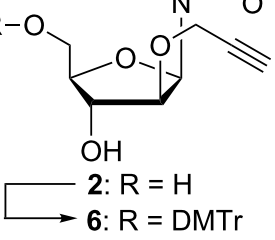

$5^{\prime} \mathrm{G}-\mathrm{G}-\mathrm{C}-\mathrm{T}-\mathrm{A}-\mathrm{T}-\mathrm{T}-\mathrm{A}-\mathrm{A}-\mathrm{T}-\mathrm{A}-\mathrm{X}-\mathrm{A}-\mathrm{A}-\mathrm{C}-\mathrm{T}-\mathrm{C}-\mathrm{G}-\mathrm{C}-\mathrm{G} 3^{\prime}$ $g \mid$ D1, D2, D3, D4 $\begin{aligned} & \text { DNA1a: } X=2 \\ & \text { DNA1r: } X=1\end{aligned}$

5' $\mathrm{G}-\mathrm{G}-\mathrm{C}-\mathrm{T}-\mathrm{A}-\mathrm{T}-\mathrm{T}-\mathrm{A}-\mathrm{A}-\mathrm{T}-\mathrm{A}-\square-\mathrm{A}-\mathrm{A}-\mathrm{C}-\mathrm{T}-\mathrm{C}-\mathrm{G}-\mathrm{C}-\mathrm{G} 3^{\prime}$ $3^{\prime} \mathrm{C}-\mathrm{C}-\mathrm{G}-\mathrm{A}-\mathrm{T}-\mathrm{A}-\mathrm{A}-\mathrm{T}-\mathrm{T}-\mathrm{A}-\mathrm{T}-\mathrm{A}-\mathrm{T}-\mathrm{T}-\mathrm{G}-\mathrm{A}-\mathrm{G}-\mathrm{C}-\mathrm{G}-\mathrm{C} 5^{\prime}$<smiles>COCC1OC(COC)C2OC1C2OC</smiles>

DNA2aD1-DNA2aD4<smiles>COCC1OC2COC1C(OC)C2OCc1cn(CCCC2CC2)nn1</smiles>

DNA2rD1-DNA2rD4

Scheme 2: Synthesis of phosphoramidite 7 and modified DNA. a) $\mathrm{TIPDSiCl}_{2}$, pyridine, $2 \mathrm{~h}$ at $0{ }^{\circ} \mathrm{C}, 16 \mathrm{~h}$ at rt, $89 \%$; b) $1 . \mathrm{NaH}, \mathrm{THF}, 0{ }^{\circ} \mathrm{C}, 15 \mathrm{~min}$, 2. propargyl bromide, rt, $18 \mathrm{~h}, 65 \%$; c) TBAF, THF, rt, $5 \mathrm{~min}, 99 \%$; d) DMTr-Cl, pyridine, rt, $5 \mathrm{~h}, 99 \%$; e) 2-cyanoethyl- $\mathrm{N}, \mathrm{N}$-diisopropylchlorophosphoramidite, (iPr) $)_{2} \mathrm{NEt}, \mathrm{CH}_{2} \mathrm{Cl}_{2}$, rt, $3 \mathrm{~h}, 95 \%$; f) automated DNA synthesis; g) D1-D4, sodium ascorbate, TBTA, $\left(\mathrm{CH}_{3} \mathrm{CN}\right)_{4} \mathrm{CuPF}_{6}$, $\mathrm{H}_{2} \mathrm{O} / \mathrm{DMSO} / \mathrm{t}-\mathrm{BuOH}$ $3: 3: 1,1.5 \mathrm{~h}, 60{ }^{\circ} \mathrm{C}$; annealing with counterstrand for $10 \mathrm{~min}$ at $90^{\circ} \mathrm{C}$ and slow cooling to rt. For structures of D1-D4 see Scheme 3.

Table 1: Melting temperatures $\left(T_{\mathrm{m}}\right)$ and fluorescence quantum yields $\left(\Phi_{\mathrm{F}}\right)$ of singly modified DNA2aD1-DNA2rD4.

\begin{tabular}{cccccc} 
dye & $\begin{array}{c}\lambda_{\text {exc }} \\
(\mathrm{nm})\end{array}$ & $\begin{array}{c}\text { DNA2a... } \\
T_{\mathrm{m}}\left[{ }^{\circ} \mathrm{C}\right]\end{array}$ & $\Phi_{\mathrm{F}}$ & $\begin{array}{c}\text { DNA2r... } \\
T_{\mathrm{m}}\left[{ }^{\circ} \mathrm{C}\right]\end{array}$ & $\Phi_{\mathrm{F}}$ \\
\hline$\ldots . D 1$ & 389 & 61.9 & $0.096^{\mathrm{a}}$ & 65.7 & $0.052^{\mathrm{a}}$ \\
$\ldots . \mathrm{D} 2$ & 462 & 61.7 & $0.452^{\mathrm{b}}$ & 64.0 & $0.266^{\mathrm{b}}$ \\
$\ldots$. D3 & 450 & 64.2 & $0.136^{\mathrm{c}}$ & 65.1 & $0.122^{\mathrm{c}}$ \\
$\ldots$. D4 & 462 & 64.2 & $0.156^{\mathrm{d}}$ & 65.2 & $0.087^{\mathrm{d}}$ \\
\hline
\end{tabular}

${ }^{\mathrm{a}} \lambda_{\mathrm{em}}=404-800 \mathrm{~nm} ;{ }^{\mathrm{b}} \lambda_{\mathrm{em}}=477-800 \mathrm{~nm} ;{ }^{c} \lambda_{\mathrm{em}}=480-800 \mathrm{~nm} ;{ }^{\mathrm{d}} \lambda_{\mathrm{em}}=$ $473-800 \mathrm{~nm}$. arabino-modified duplexes show a smaller stabilization effect by the dyes than the corresponding ribo-modified duplexes. The stabilization of dsDNA2a ranges only from $0.7{ }^{\circ} \mathrm{C}$ for D1 to $3.2{ }^{\circ} \mathrm{C}$ for $\mathbf{D 3}$ and $\mathbf{D 4}$, whereas the stabilizing effects for dsDNA2r are more diverse, ranging from $2.0^{\circ} \mathrm{C}$ for D1 to $3.7{ }^{\circ} \mathrm{C}$ for D3. Obviously, the dye interactions with doublestranded DNA do slightly depend on the type of dye. In D1 and D2, the pyridinium part is connected to the rest of the dye by its 4-position, in D3 and D4 via its 2-position. The latter connectivity has a larger stabilizing influence on the DNA2a double strands. The fluorescence quantum yields of dsDNA2a are all 
higher than the corresponding ones of dsDNA2r. Especially in case of $\mathbf{D} 2 \Phi_{\mathrm{F}}$ could be significantly improved from $27 \%$ to $45 \%$, and in case of $\mathbf{D} 4$ from $9 \%$ to $16 \%$. This is remarkable and clearly shows that the arabino-configured nucleoside 2 provides the structurally optimized anchor for fluorescent dye interactions with the DNA. Obviously, placing the dyes into the major groove led them find a better orientation than in the minor groove, with respect to the DNA helix with enhanced fluorescence intensities.
The dyes D1-D4 as energy donors were combined with dyes D5-D9 as energy acceptors (Scheme 3). This approach follows our concept of "DNA/RNA traffic lights" [17,19,25] that are energy transfer-based nucleic acid probes that can be used in molecular beacons [26], especially for vesicular microRNA imaging in living cancer cells [27], and for siRNA transport imaging [28]. Donor and acceptor dyes are combined in an interstrand and diagonal orientation to promote best possible energy transfer. In particular, we combined each of the eight

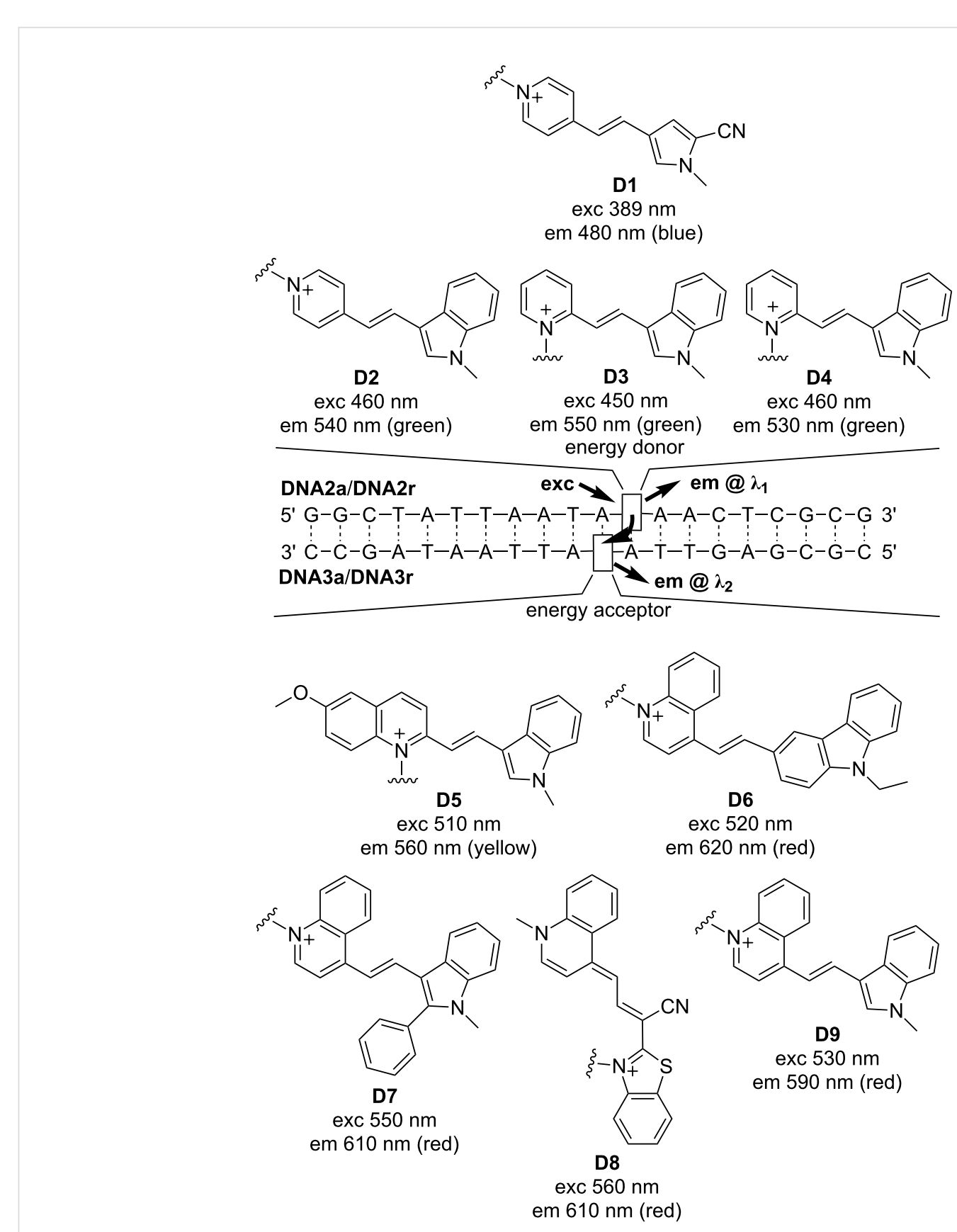


oligonucleotides DNA2a and DNA2r modified with D1-D4 with each of the ten oligonucleotides DNA3a and DNA3r modified with D5 [29], D6 [25], D7 [30], D8 [19] and D9 [29]. In detail, the blue emitting dye D1 combines to a blue-yellow fluorophore pair (D1/D5) and to blue-red emitting pairs (D1/ D6-D1/D9). The green emitting dyes D2-D4 result all in green-red emitting pairs (D2/D7-D4/D9). The combination of dyes D2-D4 with D5 and D6 is not meaningful for this concept since the fluorescence of the donors and absorption of the acceptors show broad spectral overlays and therefore selective excitation is not possible.

For each of the previously described dye combinations, we probed all four combinations of arabino- and ribo-configured donor strands (DNA2a and DNA2r) with acceptor strands (DNA3a and DNA3r). This array of doubly modified DNA duplexes was screened by their emission color contrast $\mathrm{C}=I_{\mathrm{Ac}} / I_{\mathrm{Do}}$ (fluorescence intensity near maximum of acceptor divided by fluorescence intensity near maximum of donor) and for the fluorescence quantum yield $\Phi_{\mathrm{F}}$ in the range of the acceptor emission (Table 2). The comparison with our previously applied approach to link both donor and acceptor dyes at ribo-configured nucleoside 1 (in DNA2r and DNA3r) revealed that the emission color contrasts are not improved when they are both anchored at the arabino-configured nucleoside $\mathbf{2}$ (in DNA2a and DNA3a). There are only very few excemptions; especially the combination DNA2aD4-DNA3aD8 yields a red-to-green contrast of 83 compared to 45 in case of the ribo-configured DNA2rD4-DNA3rD8. Additionally, the fluorescence quantum yield was improved from $39 \%$ to 53\%. The dye combination D2/D8 nicely demonstrates the effect of the arabino-configured attachment because the corresponding duplexes show all enhanced quantum yields whereas the pure ribo configuration in DNA2rD2-DNA3rD8 quenches its fluorescence significantly. The latter example (DNA2rD2-DNA3rD8) shows an altered absorbance of the two dyes which gives an important photophysical insight. An efficient energy transfer between two dyes requires the selective excitation of an uncoupled donor in the proximity to an uncoupled acceptor. Hyper-/hypochromicity and/or shifted absorbance of the dyes indicate excitonic (ground state) interactions between the dyes which interfere with the energy transfer between them [31].

Among the tested combinations, there are some remarkable examples in this array in which mixed energy transfer duplexes, meaning the combination of donor dyes linked to arabinoconfigured nucleosides (DNA2a) with acceptor dyes attached to

\begin{tabular}{|c|c|c|c|c|c|c|c|c|c|}
\hline \multirow{3}{*}{$\begin{array}{l}\text { Do } \rightarrow \\
\text { Ac } \downarrow \\
\text { DNA3a and } \\
\text { DNA3r }\end{array}$} & & \multicolumn{8}{|c|}{ DNA2a and DNA2r } \\
\hline & & \multicolumn{2}{|l|}{ D1 } & \multicolumn{2}{|l|}{ D2 } & \multicolumn{2}{|l|}{ D3 } & \multicolumn{2}{|l|}{ D4 } \\
\hline & & C & $\Phi_{\mathrm{F}}$ & $\mathrm{C}$ & $\Phi_{\mathrm{F}}$ & $\mathrm{C}$ & $\Phi_{\mathrm{F}}$ & $\mathrm{C}$ & $\Phi_{\mathrm{F}}$ \\
\hline \multirow[t]{4}{*}{ D5 } & $\mathbf{a}-\mathbf{a}$ & 35 & $0.146^{a}$ & - & - & - & - & - & - \\
\hline & $a-r$ & 198 & 0.606 & - & - & - & - & - & - \\
\hline & $\mathbf{r}-\mathbf{a}$ & 129 & 0.224 & - & - & - & - & - & - \\
\hline & $r-r$ & 70 & 0.217 & - & - & - & - & - & - \\
\hline \multirow[t]{4}{*}{ D6 } & $a-a$ & 15 & $0.148^{b}$ & - & - & - & - & - & - \\
\hline & $a-r$ & 48 & 0.227 & - & - & - & - & - & - \\
\hline & $\mathbf{r}-\mathbf{a}$ & 11 & 0.127 & - & - & - & - & - & - \\
\hline & $r-r$ & 40 & 0.206 & - & - & - & - & - & - \\
\hline \multirow[t]{4}{*}{ D7 } & $a-a$ & 44 & $0.273^{c}$ & 20 & $0.237^{d}$ & 41 & $0.198^{d}$ & 69 & $0.212^{d}$ \\
\hline & $a-r$ & 85 & 0.357 & 36 & 0.245 & 177 & 0.319 & 39 & 0.214 \\
\hline & $\mathbf{r}-\mathbf{a}$ & 46 & 0.213 & 10 & 0.210 & 82 & 0.218 & 108 & 0.268 \\
\hline & $r-r$ & 93 & 0.340 & 60 & 0.312 & 136 & 0.218 & 153 & 0.229 \\
\hline \multirow[t]{4}{*}{ D8 } & $\mathbf{a}-\mathbf{a}$ & 109 & $0.606^{c}$ & 20 & $0.466^{\mathrm{e}}$ & 41 & $0.528^{f}$ & 83 & $0.672^{e}$ \\
\hline & $a-r$ & 80 & 0.576 & 12 & 0.427 & 43 & 0.564 & 48 & 0.592 \\
\hline & $\mathbf{r}-\mathbf{a}$ & 215 & 0.719 & 15 & 0.378 & 77 & 0.549 & 86 & 0.534 \\
\hline & $r-r$ & 87 & 0.545 & 3 & 0.078 & 40 & 0.388 & 45 & 0.366 \\
\hline \multirow[t]{4}{*}{ D9 } & $\mathbf{a}-\mathbf{a}$ & 60 & $0.307^{\mathrm{g}}$ & 11 & $0.222^{h}$ & 9 & $0.148^{h}$ & 28 & $0.220^{h}$ \\
\hline & $a-r$ & 58 & 0.306 & 23 & 0.245 & 62 & 0.285 & 27 & 0.258 \\
\hline & $\mathbf{r}-\mathbf{a}$ & 215 & 0.240 & 7 & 0.132 & 30 & 0.237 & 34 & 0.184 \\
\hline & $r-r$ & 69 & 0.245 & 25 & 0.226 & 59 & 0.244 & 38 & 0.206 \\
\hline
\end{tabular}

\footnotetext{
${ }^{\mathrm{a}} \lambda_{\mathrm{exc}}=389 \mathrm{~nm}, \lambda_{\mathrm{em}}=515-800 \mathrm{~nm} ;{ }^{\mathrm{b}} \lambda_{\mathrm{exc}}=389 \mathrm{~nm}, \lambda_{\mathrm{em}}=525-800 \mathrm{~nm} ;{ }^{\mathrm{c}} \lambda_{\mathrm{exc}}=389 \mathrm{~nm}, \lambda_{\mathrm{em}}=550-800 \mathrm{~nm} ;{ }^{\mathrm{d}} \lambda_{\mathrm{exc}}=435 \mathrm{~nm}, \lambda_{\mathrm{em}}=550-800 \mathrm{~nm} ;$
} ${ }^{\mathrm{e}} \lambda_{\mathrm{exc}}=430 \mathrm{~nm}, \lambda_{\mathrm{em}}=550-800 \mathrm{~nm} ;{ }^{\mathrm{f}} \lambda_{\mathrm{exc}}=430 \mathrm{~nm}, \lambda_{\mathrm{em}}=540-800 \mathrm{~nm} ;{ }^{\mathrm{g}} \lambda_{\mathrm{exc}}=389 \mathrm{~nm}, \lambda_{\mathrm{em}}=530-800 \mathrm{~nm} ;{ }^{\mathrm{h}} \lambda_{\mathrm{exc}}=423 \mathrm{~nm}, \lambda_{\mathrm{em}}=550-800 \mathrm{~nm}$. 
ribo-configured nucleosides (DNA3r) and vice versa (DNA2r with DNA3a) yield significantly enhanced emission color contrasts. As a representative example, the fluorescence color readout for the combinations of D1 with D5 (Figure 1) ranges from green (DNA2aD1-DNA3rD5) to orange/red (DNA2rD1-DNA3aD5). Especially, the combination DNA2aD1-DNA3rD5 revealed a yellow-to-blue contrast of 198 and a quantum yield of $61 \%$. For the blue-red emitting dye combinations the highest red-to-blue contrast of 215 and the highest quantum yield of $71 \%$ is achieved in DNA2rD1-DNA3aD8. Finally, among the broadest array of green-red fluorophore pairs there are a few remarkable duplexes with superior energy transfer parameters. Representatively, it is noteworthy that the combination DNA2aD3-DNA3rD7 gives a red-to-green contrast of 177 (and a quantum yield of $32 \%$ ), and the combination DNA2rD4-DNA2aD8 shows a quantum yield of 53\% (and a red-to-green contrast of 86 ).

In order to test the functionality of the respective dyes as FRET pairs in DNA duplexes for imaging in cells, four representative duplexes, DNA2aD1-DNA3rD5, DNA2rD1-DNA3aD8, DNA2aD2-DNA3aD8 and DNA2rD4-DNA3aD8, were tested in HeLa cells. $5 \times 10^{4} \mathrm{HeLa}$ cells were transiently transfected with 15 pmol of the above mentioned DNA duplexes and Screenfect ${ }^{\circledR}$, for 24 hours at a concentration, which was not toxic for the cells (see cytotoxicity test in Supporting Information File 1), and imaged by confocal fluorescent microscopy using the excitation wavelength of the energy donor (D1, $\lambda_{\text {exc }}=405 \mathrm{~nm}, \mathbf{D 2}, \lambda_{\text {exc }}=488 \mathrm{~nm}, \mathbf{D 4}, \lambda_{\text {exc }}=488 \mathrm{~nm}$ ). To analyze the energy transfer to the energy acceptor the fluorescence of the energy donor (D1, $\lambda_{\mathrm{em}}=435-470 \mathrm{~nm}$ (blue), D2, $\lambda_{\text {em }}=490-550 \mathrm{~nm}$ (green), Figure 2, left column) and the respective energy acceptor dye (D5, $\lambda_{\text {em }}=575-750 \mathrm{~nm}$ (yellow), D8, $\lambda_{\mathrm{em}}=575-750 \mathrm{~nm}$ (red), Figure 2, middle column) was detected. In comparison to non-transfected control cells specific fluorescent staining could be observed in the perinuclear region, indicating that all dyes tested were endocytosed by the cells. The DNA duplexes preferentially accumulated in endosomal/lysosomal vesicles. The fluorescence of the energy donors, D1, D2 and D4 (Figure 2, left column), as well as the fluorescence of the energy acceptors, D5 and D8 (Figure 2, middle column), could be detected showing that fluorescence energy was transferred from the donor to the acceptor in the respective FRET pairs in the endosomal vesicles. This suggested that the DNA duplexes were still intact after transfection into cells.

\section{Conclusion}

The phosphoramidite 7 bearing the arabino-configured analog of uridine $\mathbf{2}$ that is additionally propargylated at the 2'-position was easily synthesized from commercially available nucleoside precursor 3 in 54\% yield over five steps. The fluorescence quantum yields of oligonucleotides that were postsynthetically modified by the blue emitting dye D1 and the green-emitting dyes D2-D4 were improved due to the arabino-configured anchor $\mathbf{2}$ in comparison to the conventional ribo-configured uridine 1. This rather small structural difference allows the attached fluorophores to point into the major groove. Thereby optimized dye-DNA orientations result in higher fluorescence quantum yields of these single dye modifications. The modified oligonucleotides with dyes D1-D4 were applied as energy donors together with the correspondingly modified oligonucleotides bearing the acceptor dyes D5-D9. All dyes belong to our
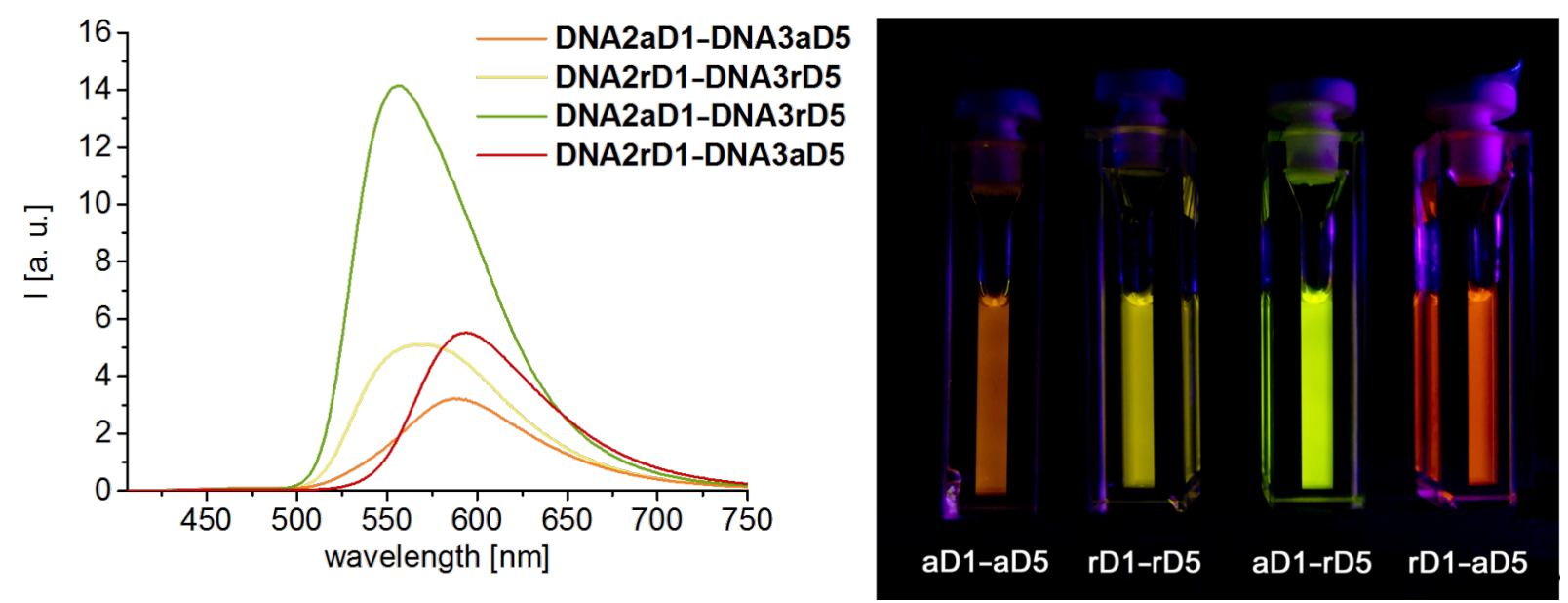

Figure 1: Representative demonstration of the fluorescence readout differences between the four arabino/ribo combinations of D1 (donor) and D5 (acceptor). Left: Fluorescence of DNA2a/rD1-DNA3a/rD5; $2.5 \mu \mathrm{M}$ DNA in $50 \mathrm{mM} \mathrm{Na-P}$ buffer, $250 \mathrm{mM} \mathrm{NaCl}, \mathrm{pH}$ 7, $\lambda_{\mathrm{exc}}=391 \mathrm{~nm}$. Right: Corresponding image of cuvettes excited by a handheld UV lamp. 

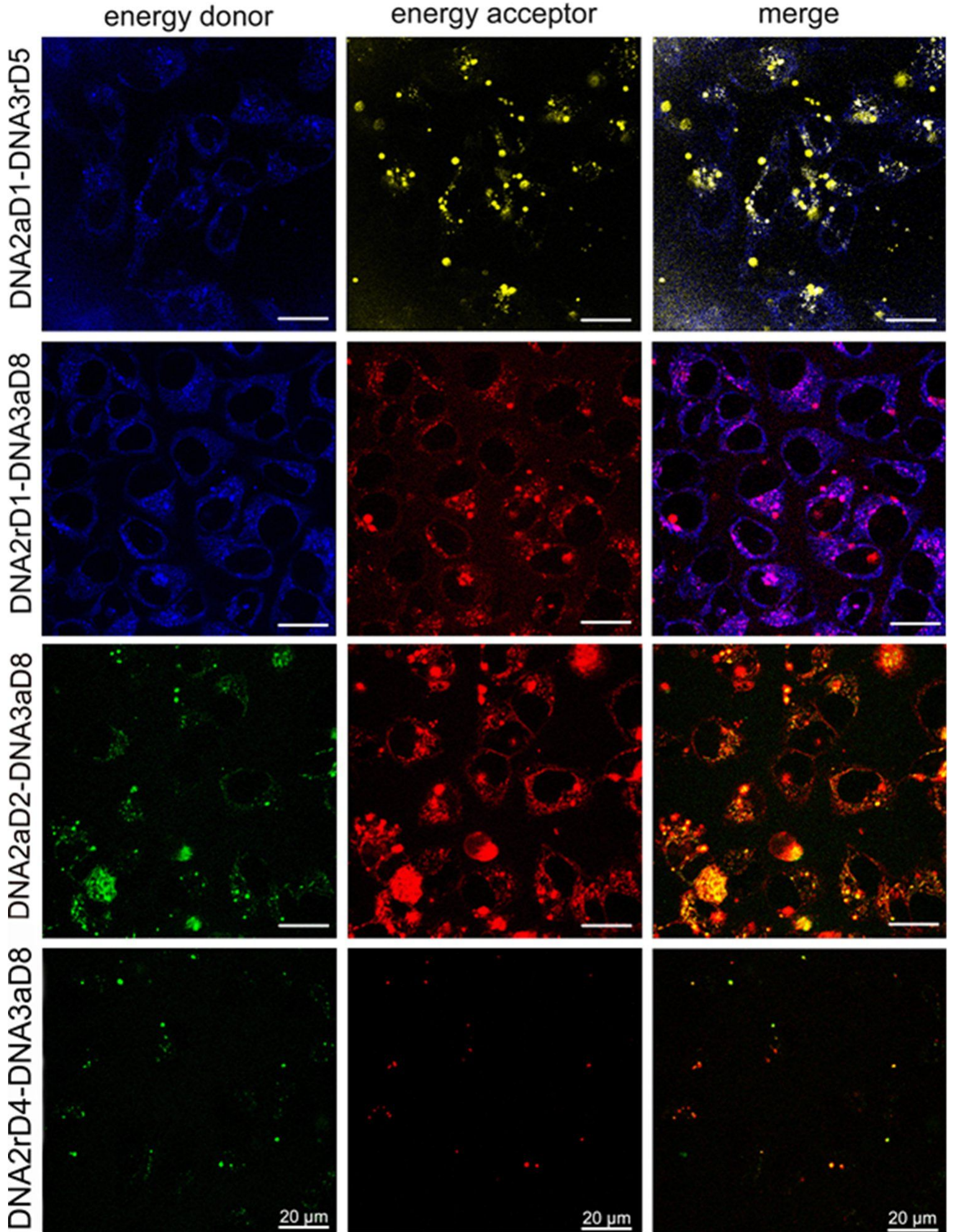

Figure 2: Confocal microscopy of HeLa cells after transfection with DNA2aD1-DNA3rD5 (row 1), DNA2rD1-DNA3aD8 (row 2),

DNA2aD2-DNA3aD8 (row 3) and DNA2rD4-DNA3aD8 (row 4). The visualization was performed using a Leica TCS-SPE (DMi8) inverted microscope with an ACS APO 63×/1.30 oil objective. For DNA2aD1-DNA3rD5 $\lambda_{\mathrm{exc}}=405 \mathrm{~nm}$ (UV laser), $\lambda_{\mathrm{em}}=435-470 \mathrm{~nm}$ (blue) and $575-750 \mathrm{~nm}$ (yellow), for DNA2rD1-DNA3aD8 $\lambda_{\mathrm{exc}}=405 \mathrm{~nm}$ (UV laser), $\lambda_{\mathrm{em}}=415-550 \mathrm{~nm}$ (blue) and $575-750 \mathrm{~nm}$ (red), for DNA2aD2-DNA3aD8 $\lambda_{\mathrm{exc}}=488 \mathrm{~nm}$ (argon ion laser), $\lambda_{\mathrm{em}}=490-550 \mathrm{~nm}$ (green) and 550-675 nm (red), for DNA2rD4-DNA3aD8 $\lambda_{\text {exc }}=488 \mathrm{~nm}$ (argon ion laser), $\lambda_{\mathrm{em}}=490-550 \mathrm{~nm}$ (green) and $675-800 \mathrm{~nm}$ (red), scale bar $=20 \mu \mathrm{m}$. 
recently established class of cyanine-styryl dyes that show excellent photostabilities. The two-by-two combinations of these dyes give energy transfer pairs with blue-to-yellow, blueto-red and green-to-red emission color changes. For these dye combinations, we probed all four combinations of arabino- and ribo-configured donor strands with arabino- and ribo-configured acceptor strands, and screened this array of doubly modified DNA duplexes by their emission color contrast $\mathrm{C}$ and the fluorescence quantum yield $\Phi_{\mathrm{F}}$. This screening revealed that the combination of donor and acceptor dyes does not necessarily yield better optical properties if they are both linked to the arabino-configured nucleoside $\mathbf{2}$ (compared to the linkage to the ribo-configured nucleoside 1). However, there are some remarkable examples in this array of duplexes with mixed combinations, that means donor dyes linked to the arabino-configured nucleoside 2 with acceptor dyes linked to the ribo-configured nucleoside $\mathbf{1}$, and vice versa, that showed significantly improved emission color contrasts and/or fluorescence quantum yields. Thereby, improved fluorescent nucleic acid probes were elucidated that are suitable not only for nucleic acid imaging of living cells but additionally allow a two-color readout.

\section{Experimental}

Materials and methods. Chemicals and dry solvents were purchased from Aldrich, ABCR, and VWR and were used without further purification unless otherwise stated. Unmodified oligonucleotides were purchased from Metabion. TLC was performed on Fluka silica gel 60 F254 coated aluminum foil. FAB mass spectra were measured by the analytical facilitites of the Institute of Organic Chemistry (KIT) using a Finnigan MAT95 in positive ionization mode. NMR spectra were recorded on a Bruker B-ACS-60, Bruker Avance DRX 400 and a Bruker Avance DRX 500 spectrometer in deuterated solvents $\left({ }^{1} \mathrm{H}\right.$ at 300,400 or $500 \mathrm{MHz},{ }^{13} \mathrm{C}$ at 75,100 or $125 \mathrm{MHz}$ ). Chemical shifts are given in ppm relative to TMS. IR spectra were recorded by the analytical facility of the Institute of Organic Chemistry (KIT) on a Bruker IFS88 spectrometer.

Optical-spectroscopic measurements were recorded in $\mathrm{NaP}_{\mathrm{i}^{-}}$ buffer solution $(10 \mathrm{mM}, \mathrm{pH} 7)$ with $250 \mathrm{mM} \mathrm{NaCl}$ in quartz glass cuvettes $(10 \mathrm{~mm})$. Absorption spectra were recorded with a Varian Cary 100 spectrometer equipped with a $6 \times 6$ cell changer unit at $20{ }^{\circ} \mathrm{C}$. Fluorescence was measured with a Jobin-Yvon Fluoromax 3 fluorimeter with a step width of $1 \mathrm{~nm}$ and an integration time of $0.2 \mathrm{~s}$. All spectra were recorded at $20{ }^{\circ} \mathrm{C}$ and are corrected for Raman emission from the buffer solution. Quantum yields were determined with Quantaurus QY C11347 of Hamamatsu.

DNA2aD1 to DNA2aD4, DNA2rD1 to DNA2rD4, DNA3aD5 to DNA3aD9 and DNA3rD5 to DNA3rD9 were purified using a reversed-phase Supelcosil ${ }^{\mathrm{TM}}$ LC-C18 column $(250 \times 10 \mathrm{~mm}$, $5 \mu \mathrm{m}$ ) on a Shimadzu HPLC system (autosampler, SIL-10AD, pump LC-10AT, controller SCL-10A, diode array detector SPD-M10A). Purification was confirmed by MS (MALDI-TOF) on a Biflex-IV spectrometer from Bruker Daltonics in the linear negative mode (matrix: 1:9 mixture of diammonium hydrogencitrate $(100 \mathrm{~g} / \mathrm{L})$ and a saturated 3 -hydroxypicolinic acid solution $(10 \mathrm{~g} / \mathrm{L}$ in $50 \%$ acetonitrile in water)). DNA concentrations were measured by their absorbance in water at $260 \mathrm{~nm}$ on a ND-1000 spectrometer from NanoDrop in the nucleic acid mode.

Synthesis of 4. 1-Deoxy-1-(uracil-1-yl)- $\beta$-D-arabinofuranose $(3,1.00 \mathrm{~g} ; 4.10 \mathrm{mmol})$ was dried under reduced pressure for $1 \mathrm{~h}$ and was then dissolved in dry pyridine $(5 \mathrm{~mL})$. The reaction mixture was cooled to $0{ }^{\circ} \mathrm{C}$ and $\mathrm{TIPDSiCl}_{2}(1.44 \mathrm{~mL}$, $4.51 \mathrm{mmol}$ ) was slowly added. After $2 \mathrm{~h}$, the reaction mixture was warmed to room temperature and stirred overnight. The solvent was removed under reduced pressure and the remaining solid was purified by flash chromatography $\left(\mathrm{SiO}_{2}, 0 \rightarrow 50 \%\right.$ EtOAc in $\left.\mathrm{CH}_{2} \mathrm{Cl}_{2}\right) .1 .78 \mathrm{~g}$ (3.66 mmol, 89\%) of $\mathbf{4}$ as a colorless solid were obtained. Spectral data were in accordance with the literature [32].

Synthesis of 5. Under argon atmosphere 4 (1.02 g, $2.10 \mathrm{mmol})$ was dissolved in dry THF $(20 \mathrm{~mL})$ and cooled to $0{ }^{\circ} \mathrm{C}$ with an ice bath. Then $\mathrm{NaH}(0.168 \mathrm{~g}, 4.20 \mathrm{mmol}$ of $60 \%$ dispersion in mineral oil) was added and the reaction mixture was stirred for 15 min at $0{ }^{\circ} \mathrm{C}$. The reaction mixture was warmed to room temperature and propargyl bromide $(0.94 \mathrm{~mL}, 1.25 \mathrm{~g}, 8.40 \mathrm{mmol})$ was added slowly within 30 minutes. The reaction was stirred for $18 \mathrm{~h}$ at room temperature and quenched by adding distilled water $(10 \mathrm{~mL})$. The mixture was extracted with ethyl acetate (two times $100 \mathrm{~mL}$ ). The combined organic layers were washed with saturated $\mathrm{NaHCO}_{3}$ solution and then dried over $\mathrm{Na}_{2} \mathrm{SO}_{4}$. The solvent was removed under reduced pressure and the residue was purified by column chromatography $\left(\mathrm{SiO}_{2}, 0-40 \%\right.$ EtOAc in hexane) to obtain $5(0.716 \mathrm{~g}, 1.37 \mathrm{mmol}, 65 \%)$ as a colorless foam. $R_{\mathrm{f}} 0.40$ (hexane/EtOAc $1: 1$ ); ${ }^{1} \mathrm{H}$ NMR $\left(400 \mathrm{MHz}, \mathrm{CDCl}_{3}\right) \delta 8.48(\mathrm{~s}, 1 \mathrm{H}, \mathrm{NH}), 7.62(\mathrm{~d}, J=8.1 \mathrm{~Hz}$, 1H, H-6), 6.22 (d, J=6.0 Hz, 1H, H-1'), 5.63 (m, 1H, OH-3'), $5.69(\mathrm{~d}, J=8.2 \mathrm{~Hz}, 1 \mathrm{H}, \mathrm{H}-5), 4.37(\mathrm{dd}, J=7.7 \mathrm{~Hz}, 6.1 \mathrm{~Hz}$, $1 \mathrm{H}, \mathrm{H}-1$ '), $4.28-4.19$ (m, 3H, $\mathrm{OCH}_{2}, \mathrm{H}-3$ '), 4.07 (dd, $\left.J=13.2 \mathrm{~Hz}, 2.4 \mathrm{~Hz}, 1 \mathrm{H}, \mathrm{H}-5_{\mathrm{a}}{ }^{\prime}\right), 4.00(\mathrm{dd}, J=13.2 \mathrm{~Hz}$, $\left.2.9 \mathrm{~Hz}, 1 \mathrm{H}, \mathrm{H}-5_{\mathrm{b}}{ }^{\prime}\right), 3.73(\mathrm{dt}, J=8.6 \mathrm{~Hz}, 2.6 \mathrm{~Hz}, 1 \mathrm{H}$, $\mathrm{H}-4$ '), $2.42(\mathrm{t}, \mathrm{J}=2.4 \mathrm{~Hz}, 1 \mathrm{H}, \mathrm{CH}), 1.11-0.95(\mathrm{~m}, 28 \mathrm{H}$, $\left.8 \times \mathrm{CH}_{3} \& 4 \times \mathrm{CH}\right) \mathrm{ppm} ;{ }^{13} \mathrm{C} \mathrm{NMR}\left(75 \mathrm{MHz}, \mathrm{CDCl}_{3}\right) \delta 160.1$ (C-4), 150.4 (C-2), 140.9 (C-6), 101.9 (C-5), 82.2 (C-1'), 82.2 (C-4'), 80.4 (C-2'), 78.9 (C-CH), $75.5(\mathrm{CH}), 72.4$ (C-3'), 60.5 $\left(\mathrm{C}-5\right.$ ') $, 59.5\left(\mathrm{OCH}_{2}\right), 17.6-17.0\left(8 \mathrm{CH}_{3}\right), 13.6-12.5(4 \mathrm{CH})$ ppm; FAB-MS m/z (\%): $525.2(65)[\mathrm{M}+\mathrm{H}]^{+}$; FAB-HRMS 
FAB $m / z:[\mathrm{M}+\mathrm{H}]^{+}$calcd for $\mathrm{C}_{24} \mathrm{H}_{41} \mathrm{~N}_{2} \mathrm{O}_{7} \mathrm{Si}_{2}{ }^{+}, 525.2447$; found, 525.2447.

Synthesis of 2. Under an Ar atmosphere $5(0.687 \mathrm{~g}, 1.31 \mathrm{mmol})$ was dissolved in dry THF $(17 \mathrm{~mL}) 1 \mathrm{M}$ tetrabutylammonium fluoride in THF $(3.28 \mathrm{~mL}, 3.28 \mathrm{mmol})$ was added. The reaction was stirred for $5 \mathrm{~min}$ at room temperature. The reaction solution was directly poured onto a short silica plug and eluted with $\mathrm{CH}_{2} \mathrm{Cl}_{2} / \mathrm{MeOH}$ 5:1. The solvent was removed under reduced pressure and the crude product was purified by column chromatography $\left(\mathrm{SiO}_{2}, \mathrm{CH}_{2} \mathrm{Cl}_{2} / \mathrm{MeOH} 10: 1\right)$ to afford $2(0.366 \mathrm{~g}$, $1.30 \mathrm{mmol}, 99 \%)$ as a colorless foam. $R_{\mathrm{f}} 0.24\left(\mathrm{CH}_{2} \mathrm{Cl}_{2} / \mathrm{MeOH}\right.$ 9:1); ${ }^{1} \mathrm{H}$ NMR (300 MHz, DMSO- $\left.d_{6}\right) \delta 11.33(\mathrm{~s}, 1 \mathrm{H}, \mathrm{NH}), 7.65$ (d, $J=8.1 \mathrm{~Hz}, 1 \mathrm{H}, \mathrm{H}-6), 6.13$ (m, 1H, H-1'), 5.63 (m, 1H, OH-3') 5.60 (d, $J=8.1 \mathrm{~Hz}, 1 \mathrm{H}, \mathrm{H}-5), 5.02$ (m, 1H, OH-5'), 4.16 (d, $\left.J=2.4 \mathrm{~Hz}, 2 \mathrm{H}, \mathrm{OCH}_{2}\right), 4.13-4.02$ (m, 2H, H-2', H-3'), 3.72-3.49 (m, 3H, H-4', 2 H-5'), 3.44 (t, $J=2.3 \mathrm{~Hz}, 1 \mathrm{H}, \mathrm{CH})$ ppm; ${ }^{13} \mathrm{C}$ NMR (126 MHz, DMSO-d $\left.d_{6}\right) \delta 163.1(\mathrm{C}-4), 150.4$ (C-2), 141.9 (C-6), 100.6 (C-5), 83.2 (C-1'), 82.8 (C-4'), 82.4 (C-2'), 79.5 (C-CH), $77.6(\mathrm{CH}), 72.5$ (C-3'), 59.9 (C-5'), 57.5 $\left(\mathrm{OCH}_{2}\right)$ ppm; FAB-MS m/z (\%): $242.3(100)[\mathrm{M}]^{+}-\mathrm{CH}_{2} \mathrm{CCH}$ (propargyl).

Synthesis of 6. Under an inert gas atmosphere 2 (0.543 g, $1.26 \mathrm{mmol})$ was dissolved in dry pyridine $(14 \mathrm{~mL}), 4,4$ 'dimethoxytrityl chloride $(0.510 \mathrm{~g}, 1.51 \mathrm{mmol})$ was added in one portion and the reaction mixture was then stirred for $5 \mathrm{~h}$ at room temperature. The reaction was quenched by adding $\mathrm{MeOH}$ $(5 \mathrm{~mL})$ and the solvents were removed under reduced pressure. The residue was dissolved in EtOAc $(20 \mathrm{~mL})$. The organic layer was washed with $1 \mathrm{M}$ aqueous $\mathrm{NaHCO}_{3}$ solution (3 times $20 \mathrm{~mL}$ ), dried over $\mathrm{Na}_{2} \mathrm{SO}_{4}$, and the solvent was removed under reduced pressure. The crude product was purified by column chromatography $\left(\mathrm{SiO}_{2}, \mathrm{CH}_{2} \mathrm{Cl}_{2} / \mathrm{MeOH} 99: 1+0.1 \% \mathrm{NEt}_{3}\right)$ to afford $6(0.729 \mathrm{~g}, 1.25 \mathrm{mmol}, 99 \%)$ as a colorless foam. $R_{\mathrm{f}} 0.13$ $\left(\mathrm{CH}_{2} \mathrm{Cl}_{2} / \mathrm{MeOH} 50: 1\right) ;{ }^{1} \mathrm{H} \mathrm{NMR}\left(400 \mathrm{MHz}, \mathrm{CDCl}_{3}\right) \delta 7.75$ (d, $J$ $=8.1 \mathrm{~Hz}, 1 \mathrm{H}, \mathrm{H}-6), 7.44-7.22(\mathrm{~m}, 9 \mathrm{H}, \mathrm{DMTr}), 6.88-6.81(\mathrm{~m}$, 4H, DMTr), 6.28 (d, $J=5.8 \mathrm{~Hz}, 1 \mathrm{H}, \mathrm{H}-1^{\prime}$ ), 5.43 (d, $J=8.2 \mathrm{~Hz}$, 1H, H-5), 4.39 (dd, $J=7.0 \mathrm{~Hz}, 5.7 \mathrm{~Hz}, 1 \mathrm{H}, \mathrm{H}-2$ '), 4.28-4.10 (m, 3H, $\mathrm{OCH}_{2}, \mathrm{H}-3$ ') 3.89 (dt, $J=7.1 \mathrm{~Hz}, 3.6 \mathrm{~Hz}, 1 \mathrm{H}, \mathrm{H}-3$ '), $3.52\left(\mathrm{dd}, J=10.8 \mathrm{~Hz}, 3.6 \mathrm{~Hz}, 1 \mathrm{H} \mathrm{H}-5_{\mathrm{a}}\right.$ '), 3.46 (dd, $J=10.8 \mathrm{~Hz}$, $3.8 \mathrm{~Hz}, 1 \mathrm{H} \mathrm{H}-5_{\mathrm{b}}{ }^{\text {') }}, 2.49$ (t, $\left.J=2.4 \mathrm{~Hz}, 1 \mathrm{H}, \mathrm{CH}\right) \mathrm{ppm} ;{ }^{13} \mathrm{C} \mathrm{NMR}$ $\left(101 \mathrm{MHz}, \mathrm{DMSO}-d_{6}\right) \delta 163.09,158.81,150.39,144.52,141.7$, $135.5,135.5,130.3,130.2,128.3,128.2,127.3,113.4,101.7$, 87.0, 83.6, 83.3, 81.0, 79.2, 77.4, 75.8, 74.0, 61.6, 59.0, 55.4 ppm; FAB-MS m/z (\%): $585.1(68)[\mathrm{M}+\mathrm{H}]^{+}$; FAB-HRMS $m / z:[\mathrm{M}+\mathrm{H}]^{+}$calcd for $\mathrm{C}_{33} \mathrm{H}_{33} \mathrm{~N}_{2} \mathrm{O}_{8}{ }^{+}, 585.2231$; found, 585.2231 .

Synthesis of 7. In a round bottom flask $6(0.196 \mathrm{~g}, 0.34 \mathrm{mmol})$ was dried overnight under vacuum and then dissolved in dry
$\mathrm{CH}_{2} \mathrm{Cl}_{2}(5 \mathrm{~mL})$ under an Ar atmosphere. $N, N$-Diisopropylethylamine $(175 \mu \mathrm{L}, 1.01 \mathrm{mmol})$ and 2-cyanoethyl $N, N$-diisopropylchlorophosphoramidite $(119 \mu \mathrm{L}, 0.50 \mathrm{mmol})$ were added. The reaction mixture was stirred for $3 \mathrm{~h}$ at room temperature and then directly purified by column chromatography $\left(\mathrm{SiO}_{2}\right.$, $\mathrm{CH}_{2} \mathrm{Cl}_{2}$ /acetone 5:1+0.1\% $\left.\mathrm{NEt}_{3}\right) .6(0.253 \mathrm{~g}, 0.32 \mathrm{mmol}$, $95 \%)$ was obtained as a colorless foam. $R_{\mathrm{f}} 0.56\left(\mathrm{CH}_{2} \mathrm{Cl}_{2} /\right.$ acetone 5:1); APCI-MS $m / z(\%)$ : $785.6(70)[\mathrm{M}+\mathrm{H}]^{+}$.

Preparation, purification and characterization of DNA. All oligonucleotides were synthesized on an Expedite 8909 Synthesizer from Applied Biosystems (ABI) using standard phosphoramidite chemistry. Reagents and CPG $(1 \mu \mathrm{mol})$ were purchased from Proligo. The commercially available ribo-configured 2'-O-propargyluridine was purchased from ChemGenes. For the arabino-configured building block 7 a slightly extended coupling time of 10 minutes was used. After preparation, the trityl-off oligonucleotides were cleaved from the resin and deprotected with conc. $\mathrm{NH}_{4} \mathrm{OH}$ at $45{ }^{\circ} \mathrm{C}$ for $16 \mathrm{~h}$.

Click reaction with modified oligonucleotides. To the lyophilized alkyne-modified DNA sample were added water $(100 \mu \mathrm{L})$, sodium ascorbate $(25 \mu \mathrm{L}$ of $0.4 \mathrm{M}$ in water $)$, tris[(1benzyl-1H-1,2,3-triazol-4-yl)methyl]amine (34 $\mu \mathrm{L}$ of $0.1 \mathrm{M}$ in $\mathrm{DMSO} / t-\mathrm{BuOH} 3: 1)$, dye azide $(114 \mu \mathrm{L}$ of $0.01 \mathrm{M}$ in DMSO/ $t$-BuOH 3:1) and tetrakis(acetonitrile) copper(I) hexafluorophosphate $(17 \mu \mathrm{L}$ of $0.1 \mathrm{M}$ in $\mathrm{DMSO} / t-\mathrm{BuOH} 3: 1)$. The reaction mixture was kept at $60{ }^{\circ} \mathrm{C}$ for $1.5 \mathrm{~h}$. After cooling to room temperature, the DNA was precipitated by adding $\mathrm{Na}_{2}$ EDTA ( $150 \mu \mathrm{L}$ of $0.05 \mathrm{M}$ in water), sodium acetate $(450 \mu \mathrm{L}$ of $0.3 \mathrm{M}$ in water) and ethanol $(10 \mathrm{~mL}, 100 \%)$ and stored at $-32{ }^{\circ} \mathrm{C}$ for $16 \mathrm{~h}$. After centrifugation, the supernatant was removed and the residue washed two times with cold ethanol $(2 \mathrm{~mL}, 80 \%)$. The dried DNA pellet was then further purified via HPLC as further described in Supporting Information File 1.

Cell experiments and confocal fluorescence microsopy. Human cervix carcinoma cells (HeLa cells) were cultured in Dulbecco's modified Eagle medium (DMEM) supplemented with $10 \%$ fetal calf serum and $1 \%$ penicillin/streptomycin at $37{ }^{\circ} \mathrm{C}$ in a $5 \% \mathrm{CO}_{2}$ atmosphere. $24 \mathrm{~h}$ before transfection $5 \times 10^{4}$ HeLa cells per well were seeded in an 8 -well chamber slide ( $\mu$ Slide 8 well ibiTreat, IBIDI, Martinsried, Germany) in $200 \mu \mathrm{L}$ of media. For the transfection $15 \mathrm{pmol}$ of the respective DNA duplexes were diluted in ScreenFect ${ }^{\circledR}$ A dilution buffer (Incella, Eggenstein-Leopoldshafen, Germany) to a final volume of $9 \mu \mathrm{L} .12 \mu \mathrm{L}$ of a $1: 10$ dilution of ScreenFect ${ }^{\circledR} \mathrm{A}$ in dilution buffer were added to the diluted DNA and rapidly mixed. A subsequent incubation time of $20 \mathrm{~min}$ at room temperature allowed the formation of lipoplexes (liposome-DNA complexes). The transfection mixture was then added to the cells. 
The cells were incubated for $24 \mathrm{~h}$ with the respective transfection mixture at $37{ }^{\circ} \mathrm{C}$ in a $5 \% \mathrm{CO}_{2}$ atmosphere. The visualization of the DNA duplexes was performed by confocal laser scanning microscopy using a Leica TCS SPE (DMi8) inverted microscope with an ACS APO $63 \times / 1.30$ oil objective. Fluorophores were excited using an UV laser $(405 \mathrm{~nm})$ for duplexes DNA2aD1-DNA3rD5 and DNA2rD1-DNA3aD8 and an argon ion laser $(488 \mathrm{~nm})$ for duplexes DNA2aD2-DNA3aD8 and DNA2rD4-DNA2aD8. The emission detection bandwidths were at 435-470 nm (blue) and 575-750 nm (yellow) for DNA2aD1-DNA3rD5, 415-550 $\mathrm{nm}$ (blue) and 575-750 nm (red) for DNA2rD1-DNA3aD8, 490-550 nm (green) and 550-675 nm (red) for DNA2aD2-DNA3aD8, 490-550 nm (green) and 675-800 $\mathrm{nm}$ (red) for DNA2rD4-DNA2aD8 Using the acquisition software Leica Application Suite (LAS) X 2.0.1.14392, the picture ratio was adjusted to $1024 \times 1024$ pixels 8 bit depth.

\section{Supporting Information}

\section{Supporting Information File 1}

Additional data and spectra.

[http://www.beilstein-journals.org/bjoc/content/ supplementary/1860-5397-13-16-S1.pdf]

\section{Acknowledgements}

Financial support by the Deutsche Forschungsgemeinschaft (Graduiertenkolleg 2039-1 and grant Wa 1386/17-1) and by Helmholtz program BIF-TM is gratefully acknowledged. B.O. was supported by a fellowship of the Landesgraduiertenförderung.

\section{References}

1. Kolb, H. C.; Finn, M. G.; Sharpless, K. B. Angew. Chem., Int. Ed. 2001, 40, 2004-2021.

doi:10.1002/1521-3773(20010601)40:11<2004::AID-ANIE2004>3.0.CO ;2-5

2. Lallana, E.; Riguera, R.; Fernandez-Megia, E. Angew. Chem., Int. Ed. 2011, 50, 8794-8804. doi:10.1002/anie.201101019

3. Gramlich, P. M. E.; Wirges, C. T.; Manetto, A.; Carell, T. Angew. Chem., Int. Ed. 2008, 47, 8350-8358. doi:10.1002/anie.200802077

4. El-Sagheer, A. H.; Brown, T. Chem. Soc. Rev. 2010, 39, 1388-1405. doi:10.1039/b901971p

5. Paredes, E.; Das, S. R. ChemBioChem 2011, 12, 125-131. doi:10.1002/cbic.201000466

6. Huisgen, R. Angew. Chem., Int. Ed. Engl. 1963, 2, 565-598. doi:10.1002/anie.196305651

7. Rostovstev, V. V.; Green, L. G.; Fokin, V. V.; Sharpless, K. B. Angew. Chem., Int. Ed. 2002, 41, 2596-2599. doi:10.1002/1521-3773(20020715)41:14<2596::AID-ANIE2596>3.0.CO $; 2-4$
8. Tornøe, C. W.; Christensen, C.; Meldal, M. J. Org. Chem. 2002, 67, 3057-3064. doi:10.1021/jo011148j

9. Chan, R.; Hilgraf, R.; Sharpless, K. B.; Fokin, V. V. Org. Lett. 2004, 6, 2853-2855. doi:10.1021/ol0493094

10. Besanceney-Webler, C.; Jiang, H.; Zheng, T.; Feng, L.; del Amo, D. S. Wang, W.; Klivansky, L. M.; Marlow, F. L.; Liu, Y.; Wu, P. Angew. Chem., Int. Ed. 2011, 50, 8051-8056. doi:10.1002/anie.201101817

11. Astakhova, I. K.; Wengel, J. Chem. - Eur. J. 2013, 19, 1112-1122. doi:10.1002/chem.201202621

12. Gramlich, P. M. E.; Warncke, S.; Gierlich, J.; Carell, T. Angew. Chem., Int. Ed. 2008, 47, 3442-3444. doi:10.1002/anie.200705664

13. Gierlich, J.; Burley, G. A.; Gramlich, P. M. E.; Hammond, D. M.; Carell, T. Org. Lett. 2006, 8, 3639-3642. doi:10.1021/ol0610946

14. Seela, F.; Xiong, H.; Leonard, P.; Budow, S. Org. Biomol. Chem. 2009, 7, 1374-1387. doi:10.1039/b822041g

15. Berndl, S.; Herzig, N.; Kele, P.; Lachmann, D.; Li, X.; Wolfbeis, O. S.; Wagenknecht, H.-A. Bioconjugate Chem. 2009, 20, 558-564. doi: $10.1021 /$ bc 8004864

16. Wenge, U.; Ehrenschwender, T.; Wagenknecht, H.-A. Bioconjugate Chem. 2013, 24, 301-304. doi:10.1021/bc300624m

17. Holzhauser, C.; Wagenknecht, H.-A. J. Org. Chem. 2013, 78, 7373-7379. doi:10.1021/jo4010102

18. Schmucker, W.; Wagenknecht, H.-A. Synlett 2012, 23, 2435-2448. doi:10.1055/s-0032-1317158

19. Bohländer, P. R.; Wagenknecht, H.-A. Eur. J. Org. Chem. 2014, 7547-7551. doi:10.1002/ejoc.201403119

20. Prakash, T. P. Chem. Biodiversity 2011, 8, 1616-1641. doi:10.1002/cbdv.201100081

21. Giannaris, P. A.; Damha, M. J. Can. J. Chem. 1994, 72, 909-918. doi:10.1139/v94-118

22. Markiewicz, W. T.; Wiewórowski, M. Nucleic Acids Res. 1978, 1 (Suppl. 1), s186-s190. doi:10.1093/nar/1.suppl_1.s185

23. Bohländer, P. R.; Vilaivan, T.; Wagenknecht, H.-A. Org. Biomol. Chem. 2015, 13, 9223-9230. doi:10.1039/C5OB01273B

24. Bohländer, P. R.; Wagenknecht, H.-A. Methods Appl. Fluoresc. 2015, 3, 044003. doi:10.1088/2050-6120/3/4/044003

25. Schwechheimer, C.; Merkel, M.; Bohländer, P. R.; Wagenknecht, H.-A. Synthetic Wavelength-Shifting Fluorescent Probes of Nucleic Acids. In Modified Nucleic Acids; Nakatani, K.; Tor, Y., Eds.; Springer International Publishing: Switzerland, 2016; pp 83-100. doi:10.1007/978-3-319-27111-8_4

26. Holzhauser, C.; Wagenknecht, H.-A. Angew. Chem., Int. Ed. 2011, 50, 7268-7272. doi:10.1002/anie.201101968

27. Bohländer, P. R.; Abba, M. L.; Bestvater, F.; Allgayer, H.; Wagenknecht, H.-A. Org. Biomol. Chem. 2016, 14, 5001-5006. doi:10.1039/C6OB00691D

28. Holzhauser, C.; Liebl, R.; Göpferich, A.; Wagenknecht, H.-A.; Breunig, M. ACS Chem. Biol. 2013, 8, 890-894. doi:10.1021/cb3006616

29. Bohländer, P. R.; Wagenknecht, H.-A. Org. Biomol. Chem. 2013, 11, 7458-7462. doi:10.1039/c3ob41717d

30. Walter, H.-K.; Bohländer, P. R.; Wagenknecht, H.-A. ChemistryOpen 2015, 4, 92-96. doi:10.1002/open.201402137

31. Barrois, S.; Wörner, S.; Wagenknecht, H.-A. Photochem. Photobiol. Sci. 2014, 13, 1126-1129. doi:10.1039/C4PP00153B 
32. Dioubankova, N. N.; Malakhov, A. D.; Stetsenko, D. A.; Gait, M. J.;

Volynsky, P. E.; Efremov, R. G.; Korshun, V. A. ChemBioChem 2003,

4, 841-847. doi:10.1002/cbic.200300678

\section{License and Terms}

This is an Open Access article under the terms of the Creative Commons Attribution License

(http://creativecommons.org/licenses/by/4.0), which permits unrestricted use, distribution, and reproduction in any medium, provided the original work is properly cited.

The license is subject to the Beilstein Journal of Organic Chemistry terms and conditions:

(http://www.beilstein-journals.org/bjoc)

The definitive version of this article is the electronic one which can be found at:

doi:10.3762/bjoc.13.16 